\title{
c-erbB-2 expression in different histological types of invasive breast carcinoma
}

\author{
S Soomro, S Shousha, P Taylor, H M Shepard, M Feldmann
}

\begin{abstract}
Sections of 149 breast carcinomas were examined for the over-expression of c-erbB-2 oncoprotein using the avidinbiotin immunoperoxidase technique and two different specific antibodies. These included the polyclonal antibody $21 \mathrm{~N}$ and the monoclonal antibody 4D5. The tumours were divided into two main groups. The first included 75 cases of invasive ductal and classic invasive lobular carcinomas. The second group consisted of 74 cases with histological types known to have a good prognosis, including mucinous, alveolar variant of invasive lobular, medullary, tubular, cribriform and papillary carcinomas. Fifteen $(20 \%)$ tumours of the first group were positive with the two antibodies. Fourteen of these were of the ductal type and one was a mixed invasive ductal and lobular carcinoma. Ten of the pure ductal cases had areas of comedo carcinoma. The intraductal elements in a further tumour were positively stained with $21 \mathrm{~N}$ antibody only. None of the second group of tumours, which included histological types known to have good prognosis, stained with 4D5, although one mucinous carcinoma was positively stained with $21 \mathrm{~N}$.

These findings suggest that in invasive breast carcinoma immunostaining for $c$-erbB-2 is mainly seen in a subgroup of ductal tumours, and that almost all other histological types, especially those associated with good prognosis, lack this expression.
\end{abstract}

Department of Histopathology, Charing Cross and Westminster Medical School, London, W6 8RF

S Soomro

S Shousha

Charing Cross Sunley

Research Centre,

London

P Taylor

M Feldmann

Genentech Inc, San Francisco, California, USA

H M Shepard

Correspondence to: Dr S Shousha

Accepted for publication 31 October 1990
c-erbB-2 (also called HER2 and neu) is a proto-oncogene which encodes a 185-190 kilodalton glycoprotein molecule that is closely related in structure to the epidermal growth factor receptor. ${ }^{1-4}$ It maps to human chromosome 17. ${ }^{5}$ Under experimental conditions, $c-e r b B-2$ becomes a potent oncogene with transforming activity only when it is overexpressed in the cells. ${ }^{6}$ In 1986 the oncogene was found to be amplified in a small percentage of adenocarcinomas of various organs, including breast, but not in other types of tumours. ${ }^{7}$

The gene product has been localised to the cell membrane with extracellular, transmembrane, and intracellular domains. ${ }^{1}$ Various specific antibodies have been raised to the extra- and intracellular domains. Repeated studies have shown a good correlation between the amplification of the $c-e r b B-2$ gene and positive immunostaining for its protein product in the cells using these specific antibodies, ${ }^{8-12}$ although overexpression of the protein product can sometimes occur in the absence of gene amplification. ${ }^{11} 12$

In breast carcinoma between $9-33 \%$ of invasive tumours overexpress the gene product, ${ }^{811-20}$ and there is strong evidence that overexpression is associated with increased tumour aggressiveness. ${ }^{11} 131719-25$ Most of these studies were carried out mainly on breast carcinomas of the ductal type. As there are other less common types of invasive breast carcinoma, some of which are known to have a relatively good prognosis, ${ }^{26}{ }^{27}$ we investigated the possibility that such tumours may have a lower incidence of $c-e r b B-2$ protein overexpression. The study was carried out using two specific antibodies, one raised to the intracellular and the other to the extracellular domains of the $c$-erb $B-2$ gene product.

\section{Methods}

Routinely processed paraffiin wax sections of 149 invasive breast carcinomas were studied. The cases were selected on the basis of their histological type and were divided into two groups. The first included 75 cases of invasive ductal and classic invasive lobular carcinomas. The second group included 74 cases with histological types known to have a good prognosis, including mucinous, medullary, tubular, cribriform, papillary and the alveolar variant of invasive lobular carcinoma (table 1). ${ }^{27}$

Two specific antibodies were used: a polyclonal antibody, $21 \mathrm{~N}$ (kindly supplied by Dr W J Gullick, ICRF Oncology Group, Hammersmith Hospital, London), raised to a synthetic peptide of the predicted sequence of the intracellular domain of $c-e r b B-2$ gene product, ${ }^{28}$ and a monoclonal antibody, 4D5 (Genentech, San Francisco, California, USA), raised to the extracellular domain of the gene product. $^{29-31}$

Four sections, each $5 \mu \mathrm{m}$ thick, were cut from a representative paraffiin wax embedded tissue block of each case. Two of these sections were intended for staining with the specific antibodies, and two were used as controls. All sections were incubated overnight at $37^{\circ} \mathrm{C}$. On the following day they were dewaxed in two changes of xylene for two minutes each and hydrated in graded alcohols. Endogenous peroxidase activity was blocked 
Table 1 c-erbB-2 immunostaining of breast carcinoma according to histological type

\begin{tabular}{lccc}
\hline $\begin{array}{l}\text { Histological type } \\
\text { (all invasive) }\end{array}$ & $\begin{array}{l}\text { Total No } \\
\text { of cases }\end{array}$ & $\begin{array}{l}\text { Cases positive } \\
\text { with 21N (\%) }\end{array}$ & $\begin{array}{l}\text { Cases positive } \\
\text { with 4D5 (\%) }\end{array}$ \\
\hline Ductal & 63 & $14(22 \%)$ & $14(22 \%)$ \\
Lobular, classic & 11 & 0 & 0 \\
Composite, ductal and lobular & 1 & 1 & 1 \\
Mucinous & 23 & $1(4 \%)$ & 0 \\
Lobular, alveolar variant & 22 & 0 & 0 \\
Medullary & 13 & 0 & 0 \\
Tubular & 6 & 0 & 0 \\
Cribriform & 6 & 0 & 0 \\
Papillary & 4 & $16(11 \%)$ & $15(10 \%)$ \\
Total & 149 & &
\end{tabular}

by $3 \%$ hydrogen peroxide in methanol for 30 minutes at room temperature. This was followed by rinsing three times in $0 \cdot 1 \mathrm{M}$ TRISbuffered-saline (TBS), pH 7.6.

Sections intended for staining with the polyclonal antibody $21 \mathrm{~N}$, and their controls, were incubated with $10 \%$ normal swine serum in TBS. Sections intended for staining with the monoclonal antibody 4D5, and their controls, were incubated in $10 \%$ normal rabbit serum. After 30 minutes excess serum was removed and sections were incubated overnight at $4^{\circ} \mathrm{C}$ either with the specific primary antisera, or, for the negative controls, with TBS.

On the following day sections were rinsed in TBS and then covered for 30 minutes with a 1 in 250 solution of the secondary antibodies in TBS (biotinylated swine anti-rabbit immunoglobulin for $21 \mathrm{~N}$, and biotinylated rabbit anti-mouse immunoglobulin for $4 \mathrm{D} 5$; both from Dakopatts, England). Sections were then rinsed three times with TBS and incubated for 60 minutes in avidin-biotin complex-horseradish peroxidase (Dakopatts, England). After rinsing in TBS sections were incubated with diaminobenzidine (DAB, Sigma, England) for six minutes and then counterstained with Harris's haematoxylin, dehydrated in graded alcohols, and mounted with Permount.

The results were assessed semiquantitatively according to the percentage of cells showing membrane staining so that (-) indicated absence of stained cells, (t) indicated staining of less than $33 \%$ of tumour cells, $(++)$ staining of $33-66 \%$ of tumour cells, and $(+++)$ staining of more than $66 \%$ of the cells. Cells showing cytoplasmic staining only were regarded as negative. ${ }^{32} 33$

\section{Results}

Only 15 tumours stained with both antibodies (table 1). Of these, 14 were invasive ductal (22\% of all ductal cases examined), 10 of which had areas of intraductal comedo elements (fig 1). The only other positive case was a composite tumour comprising two distinct zones, one invasive ductal and the other classic lobular; both showed strong positive staining $(+++)$ with the two antibodies.

Positive staining with $21 \mathrm{~N}$ was seen in two other tumours. These included a moderately stained $(t+)$ pure mucinous carcinoma (fig 2 ) and the intraductal elements of an invasive

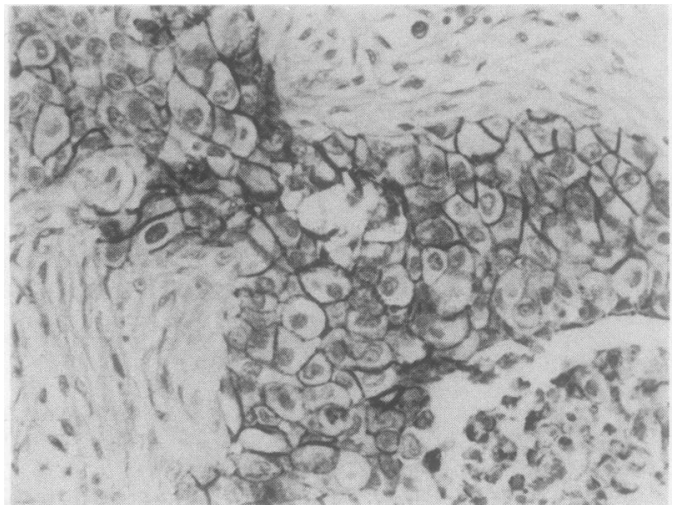

Figure 1 c-erbB-2 positive invasive ductal carcinoma (avidin-biotin complex).

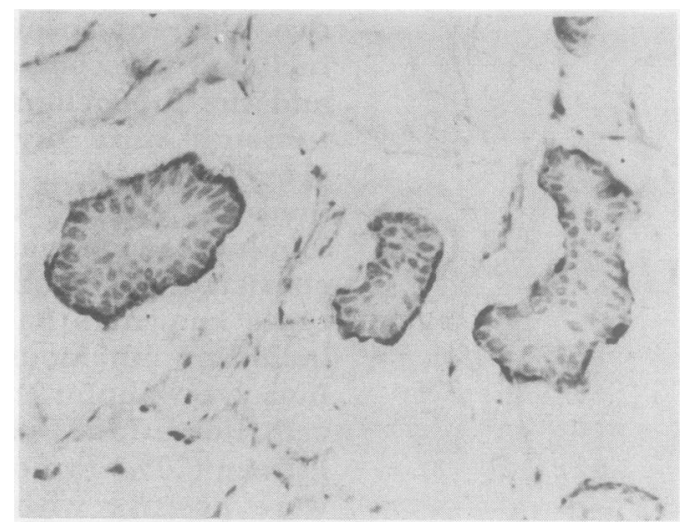

Figure 2 c-erbB-2 (21N) positive pure mucinous carcinoma (avidin-biotin complex).

Table 2 Comparison of semiquantitatively assessed staining results of $21 \mathrm{~N}$ and $4 D 5$ antibodies in invasive elements of 63 ductal carcinomas

\begin{tabular}{llllll}
\hline Antibody & Total & - & + & ++ & +++ \\
\hline 21N & 63 & 49 & 0 & 1 & 13 \\
4D5 & 63 & 49 & 2 & 6 & 6 \\
\hline
\end{tabular}

ductal tumour. These two tumours did not stain with 4D5.

All remaining 133 tumours were negative with the two antibodies. These included all pure classic and alveolar lobular carcinomas, 22 of the 23 mucinous carcinomas, and all medullary, tubular, cribriform and papillary tumours examined (table 1).

Thus the two antibodies gave concordant results in $147(98.7 \%)$ out of the 149 cases examined. In a given positive case, however, $21 \mathrm{~N}$ tended to stain more cells than 4D5 (table 2). On the other hand, cytoplasmic staining, presumably non-specific, was often seen with $21 \mathrm{~N}$, but was not encountered in cases stained with 4D5.

\section{Discussion}

The main finding of this study is the almost consistent absence of $c$-erb $B-2$ immunostaining in the uncommon histological varieties of invasive breast carcinoma, which are known to be associated with better prognosis than the common invasive ductal variety. This was 
especially so when the monoclonal antibody 4D5, which recognises the extracellular domain of the oncogene product, was used. The results obtained with the polyclonal antibody $21 \mathrm{~N}$ were similar, except for one case of mucinous carcinoma which was positive with this antibody but not with 4D5 (table 1). The findings provide indirect support for the existence of an association between positive $c-e r b B-2$ immunostaining and increased aggressiveness of invasive tumours. As most of these special types of breast carcinoma, with the exception of the medullary type, are also usually rich in oestrogen receptors, ${ }^{27}{ }^{34}$ the findings are in line with the presence, in general, of an inverse relation between $c-e r b B-2$ and oestrogen receptors. ${ }^{1825}$ 35-39

Almost all cases of invasive lobular carcinoma examined, whether classic or alveolar in type, did not overexpress this oncoprotein. The only positive lobular elements were seen in a composite tumour which consisted of separate, but adjacent, lobular and ductal parts. There are no published references about the $c-e r b B-2$ expression of the alveolar variant of lobular carcinoma, but investigators who have examined cases of the classic variant found them either all negative, ${ }^{12} 173540$ or to have included only an occasional positive case..$^{914394}$ In view of the recently reported absence of the oncoprotein in lobular carcinoma in situ ${ }^{40} 42$ the findings suggest that overexpression of $c$-erbB-2 may not have an important role in lobular neoplasia. The presence of $c-e r b B-2$ immunostaining in the composite ductal/ lobular tumour examined may indicate that the pathogenesis of the lobular-looking elements in this case is different from that of pure lobular tumours.

The only cases that were positively stained with the two antibodies used in this study were either purely or partly of ductal type, and most of these cases also contained intraductal comedo elements. This is consistent with the findings of most previous studies and strongly supports the suggestion that overexpression of $c$-erb $B-2$ oncoprotein in invasive breast carcinoma is almost totally restricted to a subset of ductal tumours with specific morphological features. $^{9164042}$ It also seems that there are only two specific types of in situ breast tumour which frequently overexpress the oncoproteinnamely, intraductal comedo carcinoma ${ }^{99} 42$ and Paget's disease of the nipple. ${ }^{40444} \mathrm{It}$ is tempting to suggest that a common thread may connect these three lesions, one invasive and two in situ, together. They are all characterised by large cell size, and although they may occasionally occur separately, they are more commonly seen in a combination of two or three; and when they do, they almost all overexpress the $c$-erbB-2 oncoprotein..$^{43}$ The neoplastic changes are probably the same and involve specific cells at specific anatomical sites, and what determines what type of lesion(s) develop(s) is the primary site of the target cell(s) involved in the neoplastic process and its original directional proliferation potential.

Our study also shows that there is an excellent correlation $(98.7 \%)$ between the immunostaining results obtained with the two antibodies used which were raised to differen domains of the oncogene product (intra- and extra-cellular). The polyclonal antibody raised to the intracellular domain $(21 \mathrm{~N})$, however, tended to stain more cells in a given case, exclusively stained two $(1 \cdot 4 \%)$ extra cases (table 2), and in some tumours showed cytoplasmic staining which is considered to be nonspecific by most authors.

We thank Dr W J Gullick of the ICRF Oncology Group Hammersmith Hospital for supplying us with the $21 \mathrm{~N}$ antibody. Photography was carried out by Mr Ron Barnett.

This study was presented in the Summer meeting of the Pathological Society of Great Britain and Ireland which was held in Nottingham, England, between 10-13 July 1990.

This work is part of Dr Soomro's PhD thesis.

1 Schechter AL, Stern DF, Vaidyanathen L, et al. The neuoncogene: an erbB related gene encoding a 185,000 $M$ tumour antigen. Nature 1984;312:513-16.

2 Coussense L, Yang-Fang TL, Liao Y-C, et al. Tyrosine kinase receptor with extensive homology to EGF receptor shares chromosomal location with neu oncogene. Science 1985;230:1132-9.

3 Yamamoto T, Ikawa S, Akiyama $T$, et al. Similarity of protein encoded by the human c-erbB-2 gene to epidermal protein encoded by the human c-erbB-2 gene to e
growth factor receptor. Nature 1986;319:230-4.

4 Akiyama T, Sudo C, Ogawara H, Toyoshima K, Yamamoto $T$. The product of the human c-erbB-2 gene: A 185 kilodalton glycoprotein with tyrosine kinase activity. Science 1986;232:1644-6.

5 Schechter AL, Hung M-C, Vaidyanathan L, et al. The neu gene: An erb B-homologous gene distinct from and unlinked to the gene encoding the EGF receptor. Science 1985;229:976-8.

6 Di Fiore PP, Pierce JH, Kraus MH, Segatto O, King CR, Aaronson SA. erb B-2 is a potent oncogene when overexpressed in NIH/3T3 cells. Science 1987;237: 178-82.

7 Yokota J, Yamamoto T, Toyoshima K, et al. Amplification of c-erbB-2 in human adenocarcinomas in vivo. Lancet c-erbB-2 in 1986 ; i:765-7.

8 Venter DJ, Tuzi NL, Kumar S, Gullick WJ. Overexpression of the c-erb B-2 oncoprotein in human breast carcinomas immunohistological assessment correlates with gene amplification. Lancet 1987;ii:69-72.

9 Van de Vijver MD, Peterse JL, Mooi WJ, et al. Neu-protein overexpression in breast cancer. Association with comedotype ductal carcinoma in situ and limited prognostic value in stage II breast cancer. N Engl J Med 1988;319:1239-45.

10 Walker RA, Senior PV, Jones JL, Critchley DR, Varley JM An immunohistochemical and in situ hybridisation study of $\mathrm{c}$-myc and c-erbB-2 expression in primary human breast carcinomas. J Pathol 1989;158:97-105.

11 Slamon DJ, Godolphin W, Jones LA, et al. Studies of the HER-2/neu proto-oncogene in human breast and ovarian HER-2/neu proto-oncogene in hu
cancer. Science 1989;244: 707-12.

12 Parkes HC, Lillycrop K, Howell A, Craig RK. C-erbB2 mRNA expression in human breast tumours: comparison with c-erbB2 DNA amplification with prognosis. $\mathrm{Br}$ Cancer 1990;61:39-45.

13 Slamon DJ, Clark GM, Wong SG, Levin WJ, Ullrich A, McGuire WJ. Human breast cancer: correlation of relapse and survival with amplification of the HER-2/neu oncogene. Science 1987;235:177-82.

14 Barnes DM, Lammie GA, Millis RR, Gullick WL, Allen DS, Altman DG. An immunohistochemical evaluation of c-erbB-2 expression in human breast carcinoma. $\mathrm{Br}$ Cancer 1988;58:448-52.

15 Gusterson BA, Machin LG, Gullick WJ, et al. C-erbB-2 expression in benign and malignant breast disease. $\mathrm{Br} J$ Cancer 1988;58:453-7.

16 Adnane J, Gaudray P, Simon M-P, Simony-Lafontaine J Jeanteur $P$, Theillet C. Proto-oncogene amplification and Jeanteur $P$, Theillet C. Proto-oncogene amplification and
human breast tumor phenotype. Oncogene 1989;4: human $1389-95$.

17 Walker RA, Gullick WJ, Varley JM. An evaluation of immunoreactivity for c-erbB-2 protein as a marker of poor short-term prognosis in breast cancer. $\mathrm{Br} J$ Cancer 1989;60:426-9.

18 Zeillinger R, Kury F, Czerwnka K, et al. HER-2 amplification, steroid receptors and epidermal growth factor receptor in primary breast cancer. Oncogene 1989;4:109-14.

19 Zhou D-J, Ahuja H, Cline MJ. Proto-oncogene abnormalities in human breast cancer: c-ERBB-2 amplification does not correlate with recurrence of disease. Oncogen 1989;4:105-8.

20 Paik S, Hazan R, Fisher ER, et al. Pathologic findings from 
the National Surgical Adjuvant Breast and Bowel Project: prognostic significance of erb B-2 protein overexpressio in primary breast cancer. $J$ Clin Oncol 1990;8:103-12.

21 Cline MJ, Battifora H, Yokota J. Proto-oncogene abnormalities in human breast cancer: correlations with anatomic features and clinical course of disease. $J$ Clin Oncol 1987;5:999-1006.

22 Varley JM, Swallow JE, Brammar WJ, Whittaker JL, Walker RA. Alterations to either c-erbB-2 (neu) or c-myc proto-oncogenes in breast carcinomas correlate with poor short-term prognosis. Oncogene 1987;1:423-30.

23 Zhou D, Battifora $H$, Yokota J, Yamamoto T, Cline MJ. Association of multiple copies of the c-erbB-2 oncogen with spread of breast carcinoma. Cancer Res 1987; 47:6123-5.

24 Tandon AK, Clark GM, Chamness GC, Ullrich A, McGuire WL. HER-2/neu oncogene protein and prognosis in breast cancer. J Clin Oncol 1989;7:1120-8.

25 De Potter C, Beghin C, Makar AP, Vandekerckhove D, Roels HJ. The neu-oncogene protein as a predictive factor for haematogenous metastases in breast cancer patients. Int J Cancer 1990;45:55-8.

26 McDivitt RW, Stewart FW, Berg JW. Tumours of the breast. Fascicle 2. In: Atlas of tumor pathology. Second breast. Fascicle 2. In: Atlas of tumor pathology. Second series. Washington,

27 Shousha S, Backhous CM, Alaghband-Zadeh J, Burn I Alveolar variant of invasive lobular carcinoma of the breast. A tumor rich in estrogen receptors. Am J Clin Pathol 1986;85:1-5.

28 Gullick WJ, Berger MS, Bennett PLP, Rothbard JB, Waterfield MD. Expression of the c-erbB-2 protein in normal and transformed cells. Int $J$ Cancer 1987;40: 246-54.

29 Hudziak RM, Schlessinger J, Ullrich A. Increased expression of the putative growth factor receptor p185HER2 causes transformation and tumorigenesis of NIH 3T3 cells. Proc Natl Acad Sci USA 1987;84:7159-63.

30 Hudziak RM, Lewis GD, Shalaby MR, et al. Amplified expression of the HER2/ERBB2 oncogene induces resistance to tumor necrosis factor alpha in NIH 3T3 cells. Proc Natl Acad Sci USA 1988;85:5102-6.

31 Hudziak RM, Lewis GD, Winget M, Fendly BM, Shepard HM, Ullrich A. p185HER2 monoclonal antibody has antiproliferative effects in vitro. and sensitizes human breast tumor cells to tumor necrosis factor. Mol Cell Biol 1989;9:1165-72.
32 Gusterson BA, Gullick WJ, Venter DJ, et al. Immunohistochemical localization of c-erbB-2 in human breast carcinomas. Mol Cell Probes 1988;2:383-91.

33 De Potter CR, Ouatacker J, Maertens G. The subcellular localization of the neu protein in human normal and localization of the neu protein in human

34 Shousha S, Coady AT, Stamp T, James KR, AlaghbandZadeh J. Oestrogen receptors in mucinous carcinoma of the breast: an immunohistological study using paraffin wax the breast: an immunohistological study

35 Garcia I, Dietrich P-Y, Aapro M, Vauthier G, Vadas L Engel E. Genetic alterations of c-myc, c-erbB-2, and c-Ha-ras protooncogenes and clinical association in human breast carcinomas. Cancer Res 1989;49:6675-9.

36 Roux-Dosseto M, Romain S, Dussault N, Martin PM. Correlation of erbB-2 gene amplification with low levels of estrogen and/or progesterone receptors in primary breast cancer: do erbB-2 products delineate hormone-independent tumors? Biomed Pharmacother 1989;43:641-9.

37 Wright C, Angus B, Nicholson S, et al. Expression of c-erbB-2 oncoprotein: a prognostic indicator in human c-erbB-2 oncoprotein: a prognostic indicator

38 Heintz NH, Leslie KO, Rogers LA, Howard PL. Amplificaion of the c-erbB-2 oncogene and prognosis of breas adenocarcinoma. Arch Pathol Lab Med 1990;114:160-3.

39 Marx D, Schauer A, Reiche Chr, et al. c-erbB2 expression in correlation to other biological parameters of breast cancer. $J$ Cancer Res Clin Oncol 1990;116:15-20.

40 Gusterson BA, Machin LG, Gullick WJ, et al. Immunohistochemical distribution of c-erbB-2 in infiltrating and in situ breast cancer. Int J Cancer 1988;42:842-5.

41 Ro J, El-Naggar A, Ro JY, et al. c-erbB-2 amplification in node negative human breast cancer. Cancer Res 1989; 49:6941-4.

42 Ramachandra S, Machin L, Ashley S, Monaghan P, Gusterson BA. Immunohistochemical distribution of c-erbB-2 in in situ breast carcinoma-A detailed morphological in in situ breast carcinoma-A

43 Lammie GA, Barnes DM, Millis RR, Gullick WJ. An immunohistochemical study of the presence of c-erbB-2 protein in Paget's disease of the nipple. Histopathology 1989;15:504-14

44 Keatings L, Sinclair J, Wright C, et al. c-erbB-2 oncoprotein expression in mammary and extramammary Paget's disease: an immunohistochemical study. Histopathology 1990;17:243-7. 